\title{
PERTUMBUHAN AKUN INSTAGRAM \\ PERPUSTAKAAN PTKIN DI INDONESIA
}

\author{
Fiqru Mafar \\ Institut Agama Islam Negeri (IAIN) Jember \\ mafarfiqru@gmail.com
}

\begin{abstract}
Abstrak
Instagram merupakan salah satu media sosial yang paling populer di masyarakat. Melihat potensi tersebut, beberapa pengelola perpustakaan perguruan tinggi mulai melirik instagram sebagai wahana informasi sekaligus mempromosikan institusi yang mereka kelola. Objek penelitian ini adalah untuk melakukan investigasi terhadap eksistensi perpustakaan PTKIN di instagram. Metode dalam penelitian ini menggunakan model kepustakaan dengan menganalisis tanggal awal posting, rata-rata posting, dan jumlah pengikut pada masing-masing akun instagram perpustakaan PTKIN di Indonesia. Hasil penelitian menunjukkan bahwa secara umum, eksistensi Perpustakaan PTKIN di instagram tergolong tinggi. Hal ini dapat dilihat terdapat 37 akun instagram dari 58 perpustakaan PTKIN di Indonesia. Dengan kata lain, lebih dari setengah atau 63,79\% perpustakaan PTKIN di Indonesia telah memanfaatkan instagram untuk mempromosikan institusi yang mereka kelola.
\end{abstract}

Kata Kunci: Instagram, Perpustakaan, PTKIN

\begin{abstract}
Instagram is one of the most popular social media in society. Seeing this potential, some university library managers have started to look at Instagram as well as promoting the institutions that they manage. The object of this research is to investigate the existence of the PTKIN library on Instagram. The method in this study uses a library model by analyzing the start date of posting, the average posting, and the number of followers on each of the PTKIN library Instagram accounts in Indonesia. The results showed that in general, the existence of PTKIN Library on Instagram was high. It can be seen that there are 37 Instagram accounts from 58 PTKIN libraries in Indonesia. In other words, more than half or $63,79 \%$ of PTKIN libraries in Indonesia have used Instagram to promote the institutions they manage.
\end{abstract}

Keywords: Instagram, Library, PTKIN 


\section{Pendahuluan}

Perpustakaan merupakan salah satu aspek penting dalam pengelolaan perguruan tinggi. Meskipun demikian, tidak sedikit dari masyarakat perguruan tinggi yang belum memanfaatkan perpustakaan dengan optimal. Salah satu hal yang sangat mempengaruhi minat untuk memanfaatkan perpustakaan perguruan tinggi adalah promosi perpustakaan ${ }^{1}$. Promosi dilakukan agar perpustakaan selalu dikenal oleh pemustaka ${ }^{2}$ sehingga mereka memiliki keterikatan dengan perpustakaan yang telah mereka kunjungi.

Saat ini hampir seluruh masyarakat Indonesia dapat mengakses internet setiap hari. Hampir setiap hari masyarakat mengakses internet, terutama untuk mengakses media sosial. Kondisi ini tentu saja menjadi peluang besar bagi pengelola perpustakaan perguruan tinggi. Munculnya media sosial dapat membuat komunikasi dilakukan tanpa batasan jarak dan waktu ${ }^{3}$.

Salah satu media sosial yang banyak digunakan oleh masyarakat adalah Instagram. Sejak dirilis pertama kali pada tahun 2010, instagram telah berevolusi menjadi media sosial yang memfokuskan diri pada konten dalam bentuk gambar. Pada tahun 2019 lalu, jumlah pengguna instagram di Indonesia mencapai lebih dari 20\% jumlah populasi yang ada ${ }^{4}$. Hal ini tentu saja menjadikan instagram sebagai media sosial yang berpotensi besar untuk mengenalkan suatu produk kepada masyarakat.

Saat ini banyak sekali pelaku usaha yang memanfaatkan konten gambar dan video pada instagram untuk memasarkan produk mereka. Era digital telah mengubah teknik pemasaran lebih menjadi lebih mengutamakan daya tarik visual ${ }^{5}$. Hal tersebut dikarenakan

${ }^{1}$ Abdul Fattah, "Pengaruh Promosi Terhadap Minat Kunjung Pemustaka di Perpustakaan Utsman ibn Affan Universitas Muslim Indonesia (UMI) Makassar,” Tesis (UIN Alauddin Makassar, 2017).

${ }^{2}$ Nova Afriani and Yunaldi Yunaldi, "Peranan Promosi Perpustakaan Terhadap Kunjungan Pemustaka di Perpustakaan Umum Kota Solok,” Ilmu Informasi Perpustakaan dan Kearsipan 1, No. 1 (2012): 9-16.

${ }^{3}$ Haryanto, "Pemanfaatan Social Media Network Sebagai Media Komunikasi Komunitas Pustakawan Homogen dalam Rangka Optimalisasi Resources Sharing Koleksi Antar Perguruan Tinggi," Pustakaloka 8, No. 1 (2016): 121-30.

4 Putut Suharso and Aninda Nurwindu Pramesti, "Promosi Perpustakaan Melalui Instagram: Studi di Perpustakaan Universitas Airlangga," Publication Library and Information Science 3, No. 2 (2020): 66-74, https://doi.org/10.24269/pls.v3i2.2074.

${ }^{5}$ Ramadita Fetrianggi, Intan Rizki Mutiaz, and Dian Widiawati, “Analisis Elemen Visual Pada Promosi Busana Muslimah di Instagram: Studi Kasus Merek Hijab Juniper Lane, Zaha, dan Zysku Xena di Bandung,” Madania 21, No. 1 (2017): 89-100. 
dibandingkan dengan konten berbentuk teks saja, gambar merupakan konten yang lebih mampu menarik pelanggan ${ }^{6}$.

Pemanfaatan instagram sebagai media pemasaran dan promosi produk ternyata tidak hanya dilakukan oleh pengusaha saja. Beberapa penelitian yang telah dilakukan oleh para peneliti sebelumnya menunjukkan bahwa instagram telah dimanfaatkan oleh beberapa perpustakan sebagai media promosi perpustakaan. Hal tersebut sebagaimana diungkapkan oleh Faisal dan Rohmiyanti dalam penelitiannya yang mengkaji tentang pemanfaatan instagram sebagai media promosi Perpustakaan Provinsi Jawa Tengah. Penelitian tersebut mengungkapkan bahwa instagram telah digunakan sebagai media promosi untuk menjaga citra perpustakaan, membangun hubungan baik dengan masyarakat melalui pengikut mereka di instagram, promosi perpustakaan, media humas, serta pemasaran langsung perpustakaan ${ }^{7}$.

Hal serupa diungkapkan oleh Hariyah dan Triyanto melalui penelitian yang telah mereka lakukan. Penelitian tersebut mengkaji tentang pemanfaatan media sosial sebagai media promosi Perpustakaan Badan Litbang dan Diklat Kementrian Agama RI. Hasil penelitian yang telah dilakukan menunjukkan bahwa Perpustakaan Badan Litbang dan Diklat Kementrian Agama RI telah memanfaatkan instagram sejak tahun 2017. Media sosial tersebut dimanfaatkan untuk media promosi kegiatan dan layanan perpustakaan yang meliputi informasi terkait koleksi yang dimiliki, pameran perpustakaan, serta informasi penting lainnya. Terbukti, melalui promosi menggunakan media sosial, salah satunya instagram, mampu meningkatkan jumlah kunjungan pada saat pameran dilakukan ${ }^{8}$.

Meskipun demikian, belum semua perpustakaan memanfaatkan instagram sebagai media promosi secara optimal. Hal tersebut terungkap dari hasil penelitian yang dilakukan oleh Miyata dan Susanto. Mereka melakukan penelitian tentang efektivitas penggunaan instagram sebagai media promosi Perpustakaan Universitas kristen Petra. Hasil penelitian yang telah mereka lakukan menunjukkan bahwa penggunaan instagram oleh Perpustakaan Universitas Kristen Petra masih belum efektif. Hal ini dikarenakan, menurut hasil penelitian tersebut, instagram yang ada masih belum memberikan informasi yang diharapkan oleh

${ }^{6}$ Wendy Abbot dkk, "An Instagram is Worth a Thousand Words: An Industry Panel and Audience Q\&A,” Library Hi Tech News 30, No. 7 (2013): 1-6.

7 Imam Agus Faisal and Yuli Rohmiyati, "Analisis Pemanfaatan Media Instagram Sebagai Promosi Perpustakaan Provinsi Jawa Tengah,” Jurnal Ilmu Perpustakaan 6, No. 4 (2017): 281-90.

8 Hariyah and Agus Triyanto, "Media Sosial Alat Promosi Perpustakaan Badan Litbang dan Diklat Kementerian Agama RI,” Media Pustakawan 25, No. 2 (2018): 32-41. 
pemustaka ${ }^{9}$. Hal ini tentunya sangat disayangkan dikarenakan melalui instagram diharapkan mampu memberikan informasi sebagai bentuk interaksi pengelola peprustakaan dengan pemustaka yang dilayani.

Berdasarkan latar belakang tersebut, penulis tertarik untuk melakukan kajian terkait pertumbuhan akun instagram Perpustakaan PTKIN di Indonesia. Penelitian ini bertujuan untuk mengetahui pertumbuhan akun instagram Perpustakaan PTKIN di Indonesia. Hasil penelitian ini diharapkan dapat memberikan salah satu gambaran tentang bagaimana pemanfaatan instagram oleh pengelola perpustakaan PTKIN di Indonesia.

\section{Metode}

Penelitian ini dilakukan melalui penelusuran terhadap akun instagram perpustakaan PTKIN di Indonesia. Daftar PTKIN diperoleh melalui jumlah yang terdaftar di laman http://diktis.kemenag.go.id/rankingtai/ptkin.php. Asumsi awal yang dibangun peneliti adalah bahwa seluruh PTKIN pada laman tersebut memiliki perpustakaan yang telah dikelola dengan baik.

Data penelitian diperoleh selama penelusuran pada tanggal 08 Desember 2020. Analisa data dilakukan pada tahun pertama kali posting, rata-rata jumlah posting dan ratarata jumlah pengikut pada akun instagram perpustakaan PTKIN di Indonesia. Perhitungan rata-rata jumlah posting dan pengikut dilakukan dengan melihat seluruh jumlah postingan dan pengikut akun yang bersangkutan. Hasil penelitian kemudian akan disajikan dalam bentuk deskriptif guna memaparkan bagaimana eksistensi perpustakaan PTKIN di Indonesia pada instagram. Sebagai bentuk etika dalam penelitian, pemaparan hasil dan pembahasan dilakukan tanpa menyebutkan identitas perguruan tinggi yang bersangkutan.

\section{Hasil dan Pembahasan}

Berdasarkan data yang terdapat di http://diktis.kemenag.go.id/rankingptai/ptkin.php, terdapat 58 PTKIN di Indonesia. Jumlah tersebut terdiri dari 17 UIN, 34 IAIN, dan 7 STAIN $^{10}$. Untuk memperoleh informasi terkait akun instagram maka dilakukan pencarian menggunakan kata kunci nama perpustakaan perguruan tinggi pada kolom pencarian situs

\footnotetext{
9 Nico Singgih Miyata and Eddy Madiono Sutanto, "Efektivitas Penggunaan Instagram Sebagai Media Promosi Perpustakaan Universitas Kristen Petra,” Agora 7, No. 2 (2019).

10 Sub Direktorat Kelembagaan Diktis, "PTKIN," 2020, http://diktis.kemenag.go.id/rankingptai/ ptkin.php.
} 
instagram. Hasil penelusuran, terdapat 37 perpustakaan PTKIN yang memiliki akun instagram, sebagaimana terlihat pada tabel berikut.

Tabel 1.

Jumlah Perpustakaan PTKIN di Indonesia yang Memiliki Akun Instagram

\begin{tabular}{|c|c|c|c|}
\hline No. & Akun Instagram & Frekuensi & Persentase \\
\hline 1 & Ada & 37 & $63,79 \%$ \\
\hline 2 & Tidak ada & 21 & $36,21 \%$ \\
\hline & Total & 58 & $100 \%$ \\
\hline
\end{tabular}

Pada saat penelusuran dilakukan, penulis menemukan terdapat dua akun instagram perpustakaan PTKIN yang belum pernah melakukan posting apapun, sehingga pada analisa tahun pertama kali dan jumlah posting tidak diikutkan dalam analisa. Selain itu, dari 37 akun instagram yang ada terdapat satu akun yang bersifat tertutup untuk publik sehingga penulis terlebih dahulu harus menjadi pengikut akun instagram yang bersangkutan untuk dapat melihat posting dan informasi lainnya pada akun tersebut.

Pertumbuhan akun instagram perpustakaan PTKIN di Indonesia dimulai pada tahun 2015. Hal tersebut dapat dilihat dari posting pertama yang dibuat oleh salah satu akun instagram muncul pada 21 Maret 2015. Pada tahun-tahun berikutnya, akun instagram perpustakaan PTKIN di Indonesia mulai bermunculan sebagaimana terlihat pada diagram sebagai berikut. 


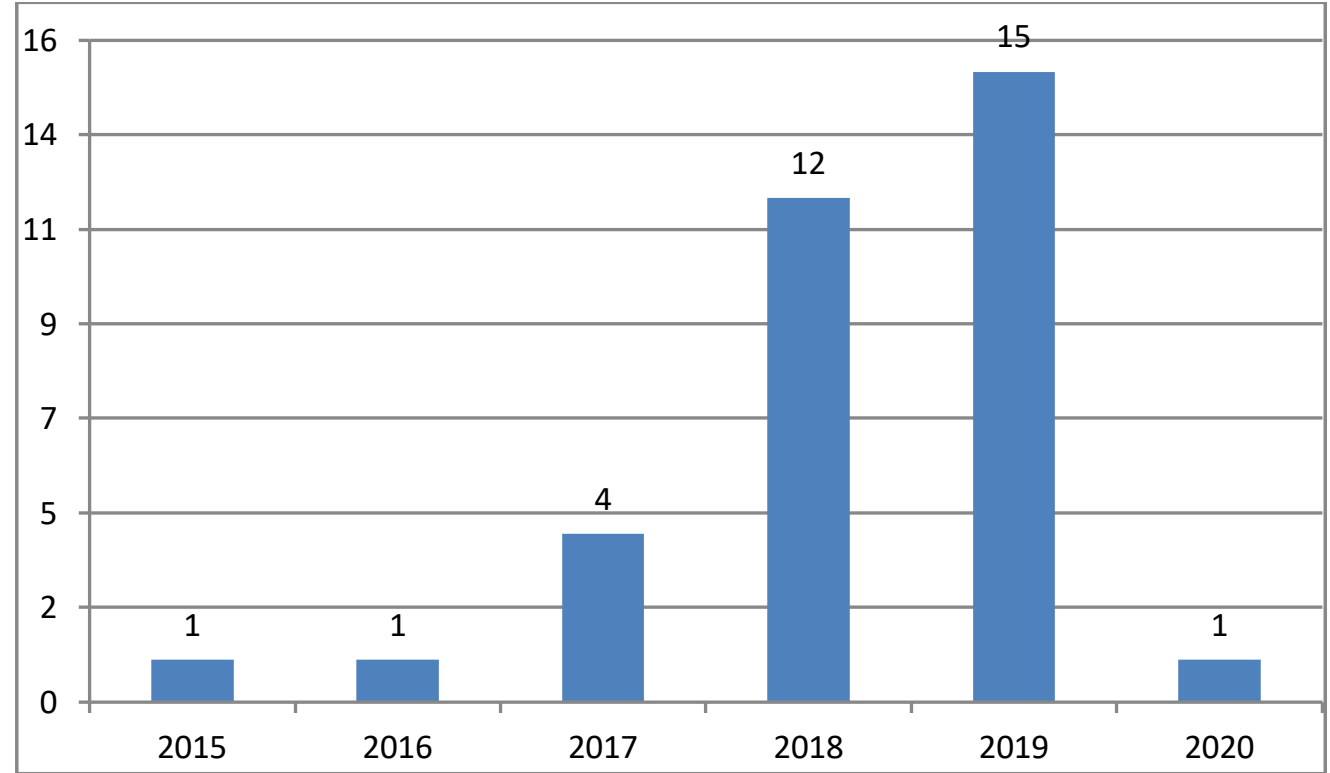

Gambar 1. Pertumbuhan Akun Instagram Perpustakaan PTKIN di Indonesia

Gambar di atas menunjukkan bahwa terdapat 34 perpustakaan PTKIN di Indonesia yang telah mulai memanfaatkan instagram sebagai media sosial untuk berkomunikasi dengan pemustaka. Pada dasarnya, terdapat dua akun tambahan, namun dikarenakan belum pernah melakukan posting sama sekali maka tidak dimasukkan ke dalam pertumbuhan akun instagram perpustakaan PTKIN.

Masing-masing akun memiliki keaktifan yang berbeda dalam memposting pada laman mereka. Hal tersebut dapat dilihat dari rata-rata jumlah postingan perhari di bawah ini.

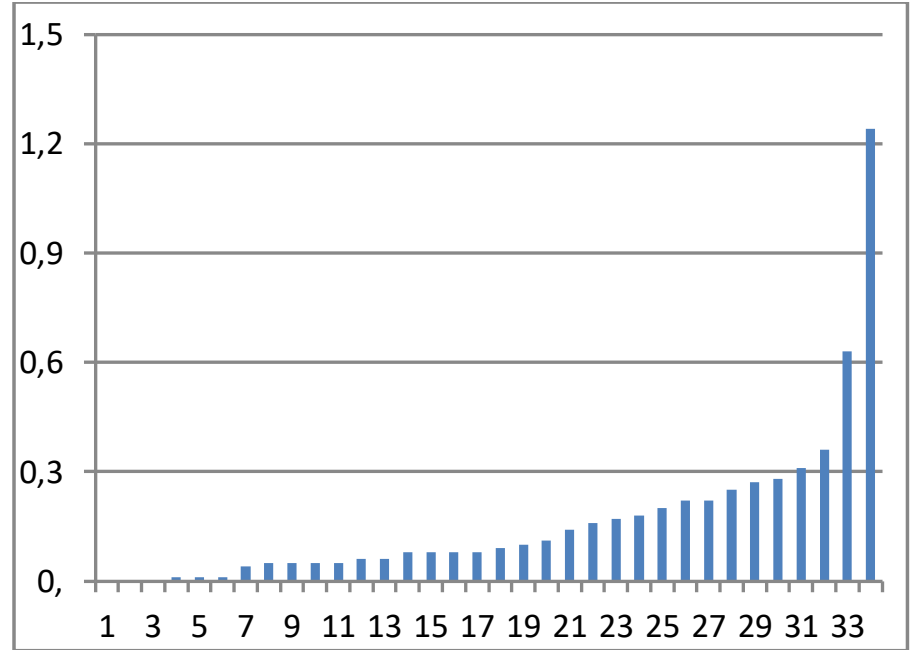

Gambar 2. Rata-rata jumlah posting perhari 
Gambar di atas menunjukkan bahwa pada umumnya, pengelola akun instagram perpustakaan PTKIN di Indonesia terlihat kurang aktif dalam memposting dan menggunakan akun instagram mereka. Hal ini dapat dilihat dari hanya satu akun saja yang memiliki rata-rata jumlah posting lebih dari satu perhari. Sisanya tercatat tidak setiap hari memposting sesuatu pada akun instagram yang mereka kelola.

Berbeda dengan jumlah rata-rata jumlah posting, beberapa akun instagram perpustakaan PTKIN di Indonesia memiliki jumlah pengikut yang cukup banyak. Bahkan terdapat 19 akun instagaram perpustakaan PTKIN yang telah memiliki ribuan pengikut.

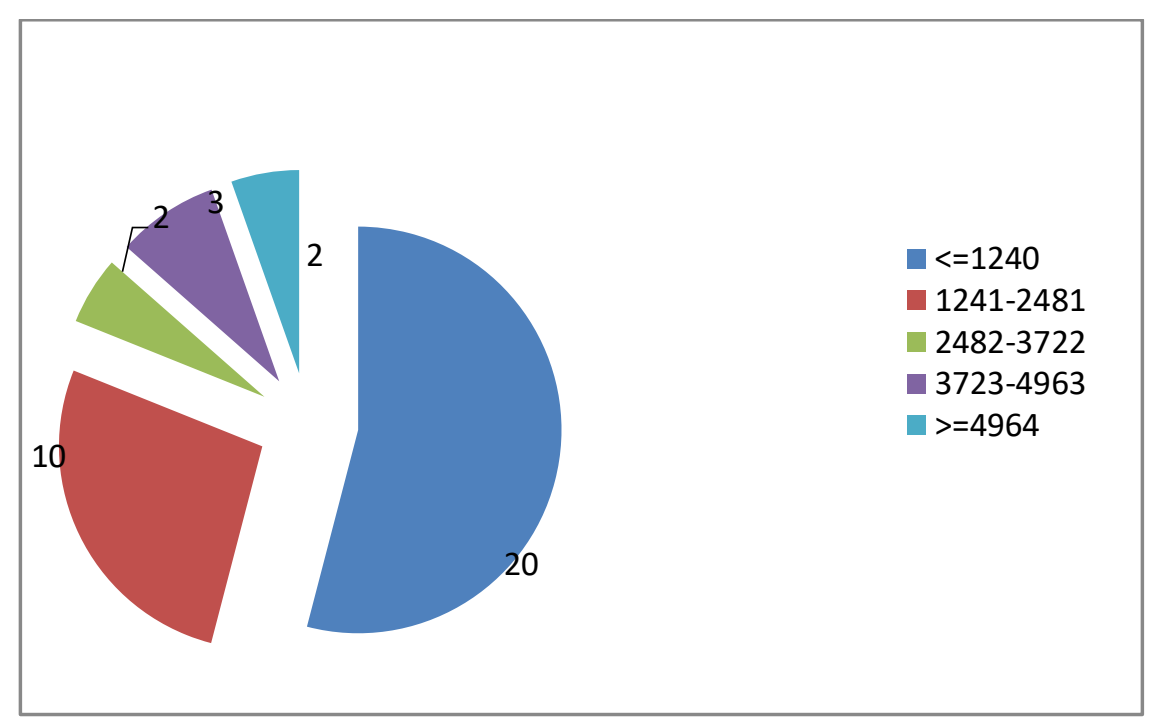

\section{Gambar 3. Jumlah Pengikut Akun Instagram Perpustakaan PTKIN di Indonesia}

Gambar di atas menggambarkan jumlah pengikut pada masing-masing akun instagram. Data di atas menunjukkan bahwa lebih dari setengah akun instagram perpustakaan PTKIN memiliki 1241-2481 pengikut. Selain itu, dapat dikatakan sebagian kecil yang memiliki pengikut 5000 pengikut.

Kondisi di atas memberikan gambaran bahwa instagram masih belum dimanfaatkan secara maksimal oleh pengelola akun. Pembuat konten harus lebih memperhatikan bagaimana instagram dapat dimanfaatan sebagai media promosi perpustakaan PTKIN yang bersangkutan. Pengelola perlu lebih memperhatikan intensitas posting dan mengelola interaksi dengan follower mereka. Melalui peningkatan aktivitas seperti di atas diharapkan mampu meningkatkan engangement rate akun instagram perguruan tinggi yang dikelola. 


\section{Simpulan}

Penelitian ini merupakan penelitian awal tentang eksistensi instagram bagi perpustakaan PTKIN di Indonesia. Hasil penelitian menunjukkan bahwa belum semua perpustakaan PTKIN yang memiliki akun instagram sebagai bagian dari kegiatan promosi mereka, yaitu sebanyak 37 perpustakaan PTKIN.

Aktivitas para konten kreator pada masing-masing akun instagram juga masih minim. Hanya dua akun perpustakaan PTKIN yang aktif melakukan menambahkan konten pada laman instagram yang mereka kelola setiap hari. Sedangkan dari segi pengikut, terdapat 19 akun instagram yang memiliki ribuan pengikut.

\section{Daftar Pustaka}

Abbot, Wendy, et al. "An Instagram Is Worth a Thousand Words: An Industry Panel and Audience Q\&A.” Library Hi Tech News 30, No. 7 (2013): 1-6.

Afriani, Nova and Yunaldi Yunaldi. "Peranan Promosi Perpustakaan terhadap Kunjungan Pemustaka di Perpustakaan Umum Kota Solok." Ilmu Informasi Perpustakaan dan Kearsipan 1, No. 1 (2012): 9-16.

Faisal, Imam Agus, and Yuli Rohmiyati. "Analisis Pemanfaatan Media Instagram Sebagai Promosi Perpustakaan Provinsi Jawa Tengah." Jurnal Ilmu Perpustakaan 6, No. 4 (2017): 281-90.

Fattah, Abdul. "Pengaruh Promosi Terhadap Minat Kunjung Pemustaka di Perpustakaan Utsman Bin Affan Universitas Muslim Indonesia (UMI) Makassar." Tesis. UIN Alauddin Makassar, 2017.

Fetrianggi, Ramadita, Intan Rizki Mutiaz, and Dian Widiawati. "Analisis Elemen Visual pada Promosi Busana Muslimah di Instagram: Studi Kasus Merek Hijab Juniper Lane, Zaha, dan Zysku Xena di Bandung.” Madania 21, No. 1 (2017): 89-100.

Hariyah, and Agus Triyanto. "Media Sosial Alat Promosi Perpustakaan Badan Litbang Dan Diklat Kementerian Agama RI.” Media Pustakawan 25, No. 2 (2018): 32-41. 
Haryanto. "Pemanfaatan Social Media Network Sebagai Media Komunikasi Komunitas Pustakawan Homogen dalam Rangka Optimalisasi Resources Sharing Koleksi Antar Perguruan Tinggi." Pustakaloka 8, No. 1 (2016): 121-30.

Miyata, Nico Singgih, and Eddy Madiono Sutanto. "Efektivitas Penggunaan Instagram Sebagai Media Promosi Perpustakaan Universitas Kristen Petra." Agora 7, No. 2 (2019).

Sub Direktorat Kelembagaan Diktis. "PTKIN," 2020. http://diktis.kemenag.go.id/ rankingptai/ ptkin.php.

Suharso, Putut, and Aninda Nurwindu Pramesti. "Promosi Perpustakaan Melalui Instagram: Studi di Perpustakaan Universitas Airlangga." Publication Library and Information Science 3, No. 2 (2020): 66-74. https://doi.org/10.24269/pls.v3i2.2074. 